\title{
Jesus en die sosiaal-veragtes
}

\author{
AG van Aarde \\ Universiteit van Pretoria
}

\begin{abstract}
Jesus and the social outcasts

The article argues that Jesus, as a first century Jew, must be seen as part of the social outcasts of his days. The group, however, should not anachronistically be treated from modern economical and political perspectives. It is illustrated how the social outcasts are led by Jesus to an existence of trust in the presence of God in spite of depressive circumstances and the apparent elusiveness of God.
\end{abstract}

Finally, in all this there is something else that we must not forget. Because God is God, because he is not part of our world and therefore not part of our development of this world, he cannot be confined or limited in any human liberation movement or liberation of self ... The name of God, for Christians symbolized in the name Jesus Christ, can be misused not only by oppressors but also by liberators. This is the proviso which follows from the 'divine way' in which he is a liberating God - liberating constantly by means of men and women, but at least in the end never in a purely human way (Schillebeeckx 1987: 14).

\section{INLEIDING}

In hierdie voordrag wil ons kortliks die verhouding tussen Jesus en die tydgenootlike sosiaal-veragtes bespreek. Ons sal vandag waarskynlik hierdie groep as die politieke en ekonomiese verontregtes beskou. Die standpunt word in die voordrag beredeneer dat ons in die Nuwe Testament met betrekking tot hierdie verhouding nie met teenoorstaandes te doen het nie, maar dat Jesus ' $n$ lid was van die sosiaal-veragtes as groep. Ons toon die denkraamwerk aan waarbinne Jesus en die

\footnotetext{
- Voordrag gelewer by geleentheid van die CB Powell-Bybelskool, UNISA-Winterskool 4-6 Julie 1988: Die eerste Christene and hulle samelewing.
} 
sosiaal-veragtes met vertroue op God se teenwoordigheid staatgemaak het en sinvol in 'n neerdrukkende wêreld voortbestaan het. Maar dit is nadat ons eers bepaal het wie en wat die sosiaal-veragtes in die tyd van Jesus self was. Ons betoog is in die lig van ons aanhaling van Edward Schillebeeckx hierbo dat die bevrydende implikasies van die evangelie deur onderdrukkers en bevryders in die twintigste eeu misbruik kan word. Eers wys ons op die Godsvertroue van die aardse Jesus. Daarna wys ons op die boodskap van die evangelie dat hierdie Godsvertroue bevrydende implikasies het vir sosiaal-veragtes ten spyte van hulle neerdrukkende omstandighede en die skynbare afwesigheid van God. Die sosiaal-veragtes word deur Jesus gelei tot' $n$ bestaan van vertroue in die teenwoordigheid van God.

\section{DIE JESUS-SAAK}

Die Evangelies in die Nuwe Testament is van die belangrikste dokumente waaruit ons ons inligting met betrekking tot Jesus van Nasaret en sy konteks kan bekom. Die soort skryfwerk in die Evangelies is egter van so ' $n$ aard dat ons dit nie sonder meer kan gebruik om die presiese woorde van en die feite rakende Jesus en sy samelewing te rekonstrueer nie. Tog beteken dit nie dat ons nie 'n goeie idee kan vorm van die wêreld en die opvattings van die mense in Galilea en Judea gedurende die eerste dertig jaar van die eerste eeu nie. Daar is al na hierdie tydperk verwys as die jare toe die tyd ryp geword het (kyk o a Gal 4: 4). Instemming met hierdie uitspraak veronderstel 'n basiese kennis van daardie tyd.

Wanneer ons in die Evangelies lees dat Jesus dit en dat gesê of gedoen het en ons interpreteer dit in terme van die sosiale konteks wat ons op grond van hierdie en ander woorde en dade in ons 'verbeelding' gevorm het, moet ons onthou dat hierdie woorde en dade nie deur Jesus self neergeskryf is nie. Die neerskrywers van die Jesus-saak was volgelinge van Jesus wat in sy saak geglo het en die bevrydende implikasies daarvan aan ander wou meedeel. Hierdie vroeë Christene het waarskynlik nie deel uitgemaak van die laagste sosio-ekonomiese klas in hulle onderskeie samelewings nie (kyk Meeks 1983). Hulle was nie mense op straat, werkloos en ontwortel ten opsigte van huisgesinne en ander verbande nie. In die tyd van die Nuwe Testament het sulke ontwortelde mense die laagste sosio-ekonomiese klas gevorm. Mense van dié klas oefen gewoonlik nie veel invloed op hulle samelewing uit 
nie (kyk Buchanan 1964/5). Die feit dat die Evangeliste kon geskryf het en die ontwortelde mense van daardie tyd dikwels nie sulke opvoeding gehad het nie, dui juis daarop dat hulle nie mense sonder invloed in hulle onderskeie samelewings was nie. Daar kan in 'n groot mate aanvaar word dat die skrywers van die Nuwe Testament belangrike vertolkers was van 'n 'bevoorregte' wêreld en dat hierdie sosiale posisie op een of ander manier in hulle skryfwerk waarneembaar is. Dit beteken natuurlik nie dat daar nie behoeftiges onder die vroegste Christene was nie. Voorgangers, soos die aspostel Paulus (kyk Gal 2: 10 ), het hulle juis beywer om die 'armes' te help in hulle nood (kyk o a Grant 1956; Keck 1965).

Bogenoemde feite laat ' $n$ mens nadink oor hoe gekompliseerd die samestellings en boodskappe van die Evangelies in der waarheid is. Die bevrydende betekenis van dit waarop die Jesus-saak neerkom, is egter so eenvoudig dat selfs ' $n$ kind dit sy eie kan maak. Dit verander egter nie die feit dat die Evangelies leesstof is wat nie sommer sonder inspanning ontleed kan word nie. Aan die een kant kry ons die indruk dat Jesus een van die 'armes' en die 'sosiaal-veragtes' was en aan die ander kant dui ons kennis van die eerste eeu daarop dat die Jesus-saak juis ironies verder gevoer is deur mense met geleerdheid en vermoëns. Die feit dat mense lang reise na vreemde plekke kon onderneem en per skip oorsee kon gaan, is ' $n$ aanduiding daarvan dat hulle mense met geld en met ander vermoëns was. 'n Mens kan amper sê dat die Christene hulle in daardie vroeë stadium in die huise van sulke mense georganiseer het (kyk o a Filem 2). Die leiers van hierdie 'huisgemeentes' sal ons normaalweg nie soek onder diegene wat ons die 'sosiaalveragtes' sou noem nie.

Dit lyk daarom noodsaaklik dat ons sal moet probeer onderskei tussen die omstandighede wat ten tyde van die aardse Jesus geheers het en dié wat die wêreld van die Nuwe-Testamentiese skrywers en hulle vroeg-kerklike omstandighede weerspieël. Hierdie twee wêrelde is in die wordingsproses van die Evangelies gelyktydig opgeneem en geïntegreerd in mekaar ingeskuif. So byvoorbeeld is dit logies dat die gebruik van die vroegste Christene om op die patroon van die eredienste in die Joodse sinagoges gereeld vir godsdiensoefening bymekaar te kom, nie as deel van die konteks van die aardse Jesus beskou moet word nie. Christene wat in die na-pase tydperk gereeld só bymekaar gekom het, het 'n naam gekry om hulle van die 'sinagoge' te onderskei (kyk van Aarde 1987a; Schmidt 1968). Hulle is ekklēsía genoem en ons vertaal hierdie Griekse woord met 'kerk' of 'gemeente'. Wanneer 
hierdie woord dan deur die aardse Jesus gebruik word (kyk Matt 16: 18), vermoed ons dat iets van die Evangelis se konteks hier klaarblyklik in die konteks van die aarde Jesus ingeskuif het. Hierdie spesifieke gedeelte in die Matteusevangelie het betrekking op die naamsverandering van die leier van Jesus se dissipels, Simon Barjona. Volgens die Evangelis het Jesus by daardie geleentheid vir Simon die naam 'Rots' (Petrus) gegee en gesê dat Hy sy 'kerk' op dié 'rots' sal bou. Hy het toegevoeg dat die poorte van die doderyk sy 'kerk' nie sal oorweldig nie.

Hierdie hele gedeelte is 'n goeie voorbeeld van hoe beide die wêreld van Jesus en dié van die vroegste Christene in die Evangelies deursigtig is (kyk Hahn 1986). Aan die een kant wil dit lyk of Jesus, soos baie ander Jode van sy tyd, die nabye aanbreek van God se koninkryk verwag het. Anders as in sekere strominge het Jesus die aanbreek van die koninkryk van God egter nie so voorgestel asof dit die teenswoordige wêreld skielik en onverwags op 'n katastrofale wyse sal vervang nie. In die lig van sy verkondiging dat die koninkryk van God 'naby' gekom het, het Hy volgelinge rondom Hom bymekaar gemaak en vir hulle geleer en gewys hoe om die wet van God nuut te interpreteer as blyke van gehoorsaamheid aan die wil van sy hemelse Vader. Hy het vir hulle gevra om nie vir die konsekwensies van so 'n gehoorsame gesindheid en optrede terug te deins nie. Hy was self in sy eie lewe baie konsekwent hieromtrent. Die omstandighede waaronder Hy geleef het, was neerdrukkend van aard. Die mensonterende kruisdood was die gevolg van sy integriteit. Maar juis as gevolg hiervan het die bevrydende implikasies van sy evangelie duidelik geword. Sy ' $A b b \bar{a}$-ervaring het Hom in ' $n$ neerdrukkende wêreld tot in die dood sinvol laat voortbestaan. Die woordjie ' $a b b \bar{a}$ is die Aramees vir 'pappa'. Dit is 'n woord wat Jesus gebruik het (kyk o a Mark 14: 36 ). ' $A b b \bar{a}$ is van die eerste woordjies wat 'n kindjie in 'n Joodse huishouding geuiter het (kyk Jeremias 1978). Dit het later ook die gebruik geword dat tieners steeds die woordjie met die verwysing na hulle pa gebruik het. In Grieks is dit as aanspreekvorm vertaal met 'Vader' (kyk o a Matt 11: 25 en Joh 11: 41) of met 'die Vader' (kyk Luk 10: 21b waar die bepalende lidwoord in die Afrikaanse vertaling weggelaat is). Jesus se gebruik daarvan dui daarop dat $\mathrm{Hy}$ in lewe en sterwe met vertroue op God se teenwoordigheid staatgemaak het. Hierdie selfde geloofsbelewing is ook deur Paulus oorgelewer (kyk Gal 4: 6 en Rom 8: 15). Jesus het met hierdie seun-vader verhouding ' $n$ aanduiding van sy voorstelling van die koninkryk van God gegee. Die begrip 'koninkryk veronderstel die 
gebeure 'om te heers' Die begrip 'heerskappy' weer veronderstel ' $n$ verhouding tussen ' $n$ onderdanige mindere en 'n heersende meerdere. Hierdie verbinding het vir Jesus neergekom op die gehoorsaamheid wat ' $n$ kind vir sy vader het. Die koninkryk van God is met ander woorde nie net as ' $n$ futuristiese konsep en in ' $n$ transendente sin van die woord alleen verstaan nie. In hierdie koninkryk gaan dit vir Jesus primêr om 'n seun-vader verhouding en hierdie verhouding het konsekwensies vir die lewe hier en nou. Daarom leer Jesus sy dissipels om tot ons Vader in die hemel te bid en om te vra dat hulle op aarde gehoorsaam sal wees aan die wil van ons Vader soos die 'hemelinge' in die hemel aan God gehoorsaam is (kyk Matt 6: 10). Toe Jesus as gevolg van sy konsekwente gehoorsaamheid doodgemaak is, het sekere mense en ook van sy volgelinge sy dood verstaan as 'n daad wat die katastrofale en apokaliptiese vervanging van die teenswoordige bose wêreld onder invloed van Satan en sy agente deur die toekomstige koninkryk van God gaan verhaas. Die wederkoms van Jesus is toe as dié dag gesien waarop God dit gaan doen. Charismatiese entoesiasme was die wyse waarop mense met só 'n verwagting gelowiges in die wêreld gewees het. Die uitbly van die wederkoms van die Here het dié charismatiese entoesiasme laat ontwikkel in 'n vroeg-kerklike institusionalisering waar die Heilige Gees en sy gawes baie nou verbind is met die verkondiging van die Jesus-evangelie en met ' $n$ uitkristalliserende ampsbeskouing (kyk Ef 4: 1-16). Die gereelde samekomste van die gemeente waarna daar as ekklēsía en ook as die liggaam van Christus (kyk Ef 5: 23) verwys is, het in hierdie vroeg-katolieke periode geyk geraak.

Die vermelde Jesus-uitspraak rakende Petrus se naamgewing het enersyds betrekking op die gebeurtenis dat Jesus volgelinge geroep en bepaalde eise van gehoorsaamheid met beslissende gevolge aan hulle gestel het. Andersyds dui hierdie Jesus-uitspraak op 'n konteks binne 'n spesifieke deel van die vroegste kerk waar Petrus 'n leiersposisie beklee het en waar die Christene gereeld in eredienste bymekaar gekom het. Die einde van die 'sataniese' beheersing is binne hierdie konteks nie meer as ' $n$ katastrofale gebeurtenis aan die einde van die tyd voorgestel nie. Die gehoorsaamheid aan God se wil hier en nou in hierdie wêreld is gesien as die vrywaring van die invloed van die Bose. Die uitdrukking 'die magte van die doderyk' in die Jesus-uitspraak onder bespreking verwys juis na hierdie 'sataniese' beheersing.

Dit is op grond van bogenoemde bespreking duidelik dat ten minste twee kontekste deur die Evangelies weerspieël word. Elke afsonderlike 
Evangelis het uit beide kontekste op 'n eiesoortige manier inligting geselekteer en dit na behoefte gekombineer sodat 'n 'nuwe' interpretasie van die Jesus-saak gevolg het wat met hom en sy bepaalde gemeentekring sinvol gekommunikeer het. Dit wat 'n spesifieke Evangelie ons bied, is dus daardie Evangelis se visie op en beeld van Jesus. Ons konstruksie van die Jesus-saak wat spruit uit ons eie lees van meer as een relevante geskrif, is derhalwe ook niks anders as ons eie 'verbeelde' konteks in terme waarvan ons met die Jesus-evangelie sinvol kommunikeer nie.

Daarom is dit net eerlik en wetenskaplik-konsekwent om te erken dat ook ons inligting selekteer en nuut kombineer om die Jesus-saak te konstrueer. Hiervoor is allerlei kriteria nodig sodat ons kan probeer om te onderskei tussen die omstandighede wat ten tyde van die aardse Jesus geheers het en dié wat die wêreld van die Nuwe-Testamentiese skrywers en hulle vroeg-kerklike omstandighede weerspieël. Een van hierdie kriteria is die sogenaamde kriterium van nie-ooreenstemming. Hiermee word bedoel dat ons met behulp van ons kennis van die eerste eeu deur middel van logiese afleidinge probeer bepaal watter inligting in die Nuwe Testament en aanverwante dokumente die vroeëre teenoor die latere omstandighede weerspieël. So kan ons byvoorbeeld na aanleiding van die naamgewing van Petrus sê dat dissipels in die wêreld van die aardse Jesus geroep was en dat Petrus 'n leiersfunksie onder hulle gehad het. Verder kan ons sê dat Christene in die wêreld van die vroeë kerk gereeld in formele godsdiensoefening bymekaar gekom het en dat hulle 'kerk' genoem was. Aan die een kant weer het Jesus radikale eise aan sy dissipels gestel met betrekking tot die gehoorsaamheid aan die wil van God wat tot die dood kan lei. Só 'n gehoorsaamheid is gesien as 'n manier waarop Satan se heerskappy oor mense oorwin word. Aan die ander kant het mense in die vroeë kerk die uitbly van die 'apokaliptiese' vervanging van hierdie 'bose' wêreld deur die transendente koninkryk van God begin beleef. Hulle het toe, in plaas van die gehoorsaamheid aan die wet van God, die gehoorsaamheid aan die verkondiging van Jesus se evangelie begin sien as ' $n$ manier hoe die 'kerk' gevrywaar kon word van Satan en sy engele laasgenoemde is gesien as manifesterend in byvoorbeeld die Farisese ortodoksie of in die Romeinse owerhede.

Sodoende het ons 'n soort samehangende indruk begin vorm van die wêreld van Jesus teenoor die wêreld van die vroeë kerk. Dit bring ons terselfdertyd uit by 'n tweede kriterium wat geld in ons konstruksie van 
die Jesus-saak en dit is naamlik die kriterium van koherensie. Binne so 'n samehangende geheel het ons met ' $n$ totale ander beeld van die Farisese beweging te doen as wat gegeld het in die periode tot en met die Makabeërs en die periode wat ' $n$ aanvang geneem het by die val van Jerusalem in $70 \mathrm{n} \mathrm{C}$ (kyk Wild 1985). Ons weet op grond van sekere Joodse literatuur dat beroemde Fariseërs in die periode voor-70 n C Galilea as werkplek van hulle skrifgeleerdheid gehad het. Die oorwig van getuienis dui daarop dat die Fariseërs in die tyd van Jesus hoofsaaklik tot Jerusalem beperk was. Tog impliseer Lukas 13:31 dat daar Fariseërs was wat ook in Galilea gewoon het. Op ander plekke in die Evangelies waar Jesus op Galilese bodem in strydgespekke met Fariseërs betrokke was, word daar gemeld dat hulle vanaf Jerusalem na Galilea gekom het (kyk o a Mark 3: 22 en 7: 1). Dit is egter nie heeltemal duidelik of hierdie verwysings wel die wêreld van die aardse Jesus weerspieël of dié van die Palestynse voor-Markaanse kerk nie.

Ons kan dus saamvat deur te sê dat die Farisese beweging in die tydperk van die aardse Jesus waarskynlik nie beperk was tot Judea met Jerusalem as sentrum nie (kyk Luz 1982). Dit was ook op Galilese bodem as die leefwêreld van Jesus aanwesig. Dit was 'n beweging wat, anders as die Sadduseërs, sterk a-polities georiënteerd was. Dit was veeleer ' $n$ religieuse vroomheidsbeweging wat hulle op wetsinterpretasie toegelê het. Hulle was nie 'n eenvormige groep nie, maar heterogeen en verskillende oortuigings het onder hulle voorgekom. Hulle was tot 'n hoë mate verdraagsaam, maar iets soos Godslastering het hulle nie geduld nie (vgl Mark 14: 64). Hulle het 'n futuristiese siening van die koninkryk van God gehad, maar het 'n interimetiek voorgestaan. Hulle het beslis nie tot slegs ò die ekonomies-ryk of die ekonomiesarm klas in die samelewing behoort nie. Hulle was as sodanig nie hatig op die Romeine nie en hulle het ruimte gehad dat proseliete vanuit die nie-Jodedom tot die Farisese groep toegevoeg kon wod. Belangrike figure onder die Fariseërs van daardie tydperk was rabbi's soos Hillel en Shammai. Jesus kon ook só 'n rabbi gewees het (kyk Vemes 1983). Jesus was egter nie 'n verdediger van die Farisese reinheidsvoorskrifte en tiendesgebod nie. Aan die ander kant het $\mathrm{Hy}$ die Farisese piëteit gedeel en was Hy soms self strenger as die rigiede Rabbynse tydgenoot, Shammai, soos dit blyk in Jesus se siening oor egskeiding.

Wat Jesus verder betref, kan ons minstens sê dat Hy opgetree het met die aanspraak dat God Hom gestuur het en dat Hy ook sy volgelinge wat $\mathrm{Hy}$ rondom Hom vergader het, met 'n sendingtaak in die wêreld ingestuur het, dat Hy die Joodse wet radikaal nuut geïnterpreteer en 
daarom saam met sy volgelinge in konflik met die Joodse familie- en godsdienshoofde gekom het en dat hy op konsekwente wyse met eksistensiale gevolge vir Hom en sy volgelinge die einde van die tyd begin voorsien het. Jesus het dit wat $\mathrm{Hy}$ geleer het, egter nie as onmoontlik beskou om te gehoorsaam sodat dit as 'n blote ideaal kon geld wat eers in die nie-menslike, 'ander' wêreld, naamlik die 'koninkryk van God', sal kan verwesenlik nie. Die eise van die koninkryk van God het vir Jesus konsekwensies in die lewe hier en nou gehad. Daarom het sy prediking die boodskap gehad dat die koninkryk van God 'naby' gekom het (kyk o a Mark 1: 15). Gehoorsaamheid aan die eise van die koninkryk van God is om die hele lewe in te dink in terme van dit wat God wil hê en nie in terme van dit wat die mense wil hê nie (kyk o a Mark 8: 34 en 14: 36). 'Bekering' tot God het op niks anders neergekom as juis die glo van só 'n evangelie nie (kyk weer Mark 1: 15).

Die wet as die wil van God het met ander woorde 'n baie belangrike plek in Jesus se lewe ingeneem (kyk Van Aarde 1987b). Dit laat 'n mens dink aan die vroomheidsgesindheid waarvan Psalm 1 praat: 'Dit gaan goed met die mens ... wat in die wet van die Here sy vreugde vind, dit dag en nag oordink. Hy is soos ' $n$ boom wat by waterstrome geplant is, wat op die regte tyd vrugte dra en waarvan die blare nie verdroog nie. Hy is voorspoedig in alles wat hy aanpak ...' (vgl ook Matt 7: 21, 23 en 7: 24-28). Die andersheid van Jesus se wetsinterpretasie wat die mense verbaas laat staan het (kyk o a Matt 7: 28), is die konsekwentheid, integriteit, geheelheid wat $\mathrm{Hy}$ in die gehoorsaamheid aan die wil van God geëis het (kyk Mark 12: 28-34). Hy kon byvoorbeeld nie aanvaar dat mense die regte ding doen, soos om te bid, maar met ' $n$ verkeerde motief, naamlik om deur mense gesien te word en nie deur God gehoor te word nie (kyk Matt 6:1,5-6). Om die regte ding te doen terwyl die innerlike ingesteldheid verkeerd is, is inkonsekwent en ontbreek aan geheelheid. So byvoorbeeld word moord nie gepleeg nie, maar die medemens word gehaat. Dieselfde geld vir geselekteerde wetsgehoorsaamheid. So byvoorbeeld kan iemand ' $n$ offer na die tempel bring om vergifnis van God te ontvang, maar hy wil nie sy medemens vergewe wat teenoor hom oortree het nie. Om gehoorsaam te wees aan die eise van die koninkryk van God is om 'volmaak' te wees soos ons Vader in die hemel 'volmaak' is (kyk Matt 5: 48). Om 'volmaak' te wees is om iemand met integriteit te wees. Om te sê dat God 'volmaak' is, is om te sê dat Hy gister, vandag en môre dieselfde is. Jesus was onder andere in dié sin van die woord God-by-ons. Hierdie konsekwentheid by Jesus het Hom egter in ernstige konflik met veral die tradisionele sieninge ten 
opsigte van die tempel as God se woonplek by die mense gebring. By wyse van spreke wou Hy die tempel, wat volgens Hom 'n woonplek van skynheiliges geword het (kyk Matt 12: 6-7; 21: 13; 24: 1-2; Hand 7: 48), afbreek en heropbou. Jesus se oortuiginge in hierdie verband is as Godslastering ervaar en dit het Hom sy dood gekos. Maar ook hieromtrent was $\mathrm{Hy}$, soos in die lewe so ook in die sterwe, konsekwent. Om 'skynheilig' te wees, is om inkonsekwent te wees.

\section{DIE SOSIAAL-VERAGTES}

Wat die verhouding tussen Jesus en die sosiaal-veragtes betref, behoort dit in terme van ons geheelbeeld van die Jesus-saak beskryf te word.

Ons het aan die begin van ons voordrag gesê dat ons in hierdie verhouding nie met teenoorstaandes te doen het nie, maar dat Jesus gesien moet word as 'n lid van die sosiaal-veragtes as groep. Om hierdie tese te beredeneer, is dit nodig om eers iets oorsigtelik te sê rakende die sosiale kategorieë wat oor die algemeen in die lewe onderskei kan word. Daarna bespreek ons die sosiaal-veragtes van die tyd van Jesus, en ons verwys oorsigtelik en voorlopig na hulle as die 'volk van die land'. Ons wys egter daarop dat mense buite die 'volk van die land' ook as sosiaal verag beskou kon word. Ons toon aan dat die Jesus-saak ingebed is in die neerdrukkende omstandighede waaronder die 'volk van die land' hulle bevind het en hoedat die sosiaal-veragtes volgens die Jesus-evangelie met vertroue op God se teenwoordigheid staat kon maak om sodoende sinvol in ' $n$ neerdrukkende wêreld voort te bestaan. Ten slotte word enkele implikasies van ons verstaan van Jesus en die sosiaal-veragtes aangedui vir die twintigste-eeuse standpunt dat die Jesus-evangelie gebruik kan word om die armes en die verdruktes in die samelewing te bevry.

\subsection{Sosiale kategorieë}

Dit spreek vanself dat informasie oor die sosiale dimensies en kategorieë van die mense wat geleef het in die gebied en die periode waar en wanneer die Nuwe Testament ontstaan het, ons kan help dat daar nie onbewustelik moderne idees in die Nuwe Testament ingedra word nie (kyk Schnell \& De Klerk 1987). Dit geld veral vir sake wat in ons voorstellingswêreld in ' $n$ mindere of meerdere mate abstrak figureer. Die konsepte vrede, rykdom, armoede, nederigheid, liefde ensovoorts kan sulke sake wees. Dit geld verder ook ons belewing van sosiale 
institusies soos die rol wat die samelewing, byvoorbeeld 'n man of 'n vrou, 'n gesin, 'n pa of 'n ma, God of gode, bevoorregtes of verontregtes, tyd as siklies of as liniêr, partikuliere nasionaliteit of internasionale universaliteit ensovoorts laat vervul.

Die Nuwe Testament het ontstaan in die gebied oos van die Middelandse See, tydens die Hellenistiese periode en die Jesus-saak behoort in terme van dié konteks bestudeer te word. So 'n studie toon aan dat ons hedendaagse sosiaal gestruktureerde teenstelling tussen arm en ryk, nie tipies is van wat as soortgelyk in die Nuwe Testament beskou kan word nie (kyk Blasi 1986). Om 'arm' in die Bybelse tydperk te wees, is byvoorbeeld nie noodwendig dieselfde as om ekonomies 'arm' te wees nie. Met ander woorde, as daar in die Bybel verwys word na die 'arme' Saggeus, dan is hy nie noodwendig 'n persoon wat nie geld gehad het nie.

'n Mens kan enige samelewing bestudeer in terme van deelwêrelde wat as sosiale verwantskappe voorkom (Malina 1981). Die ekonomie is só 'n verwantskap waar mense as 'n groep op 'n kollektiewe wyse materieel bevoorreg of verontreg word. Natuurlik kan sodanige bevoorregting of verontregting die gevolg wees van die individu in die groep se eie vermoë of onvermoë. Naas die ekonomie vorm die politiek ook'n sosiale verwantskap waar heersers en onderdane in terme van mag en kollektiewe organisasie voortbestaan. Bloed-en-bodem vorm ook 'n sosiale verwantskap. Hier funksioneer aspekte soos geboortelike afkoms en nasionaliteit as sosiale kragte wat 'n bydrae lewer tot lojaliteit, konsolidariteit en toegewydheid. Kollektiewe organisering op hierdie terrein kan, maar hoef nie, ekonomies en/of politieke gevolg te hê nie. Godsdiens is ook iets wat 'n sosiale groepsdimensie het. Dit blyk onder andere daarin dat daar begin is om die vroegste Christene 'kerk' te noem omdat hulle as ' $n$ groep mense bestaande uit Jode en nie-Jode vir godsdiensoefening bymekaar gekom het en daar derhalwe nie meer na hulle as 'sinagoge' verwys kon word nie (Van Aarde 1987a). Navorsing het getoon dat die term 'sinagoge' 'n sterk Joods-partikuliere konnotasie gedurende die eerste eeu gehad het, terwyl die term ekklēsía (='kerk') as gevolg van Hellenistiese invloed 'n universele konnotasie begin kry het. Partikulariteit en universaliteit is sake wat dus in hierdie verband betrekking het op sosio-religieuse groepsdimensies.

Godsdiens as 'n sosiale verwantskap verskaf in 'n groot mate die waardes of minstens die gewete wat sake aanspreek met betrekking tot familie-aangeleenthede en nasionaliteit, politiek en ekonomie. Dit beteken egter nie dat godsdiens in alle kulture en samelewings die 
botoon voer nie. Enigeen van bogenoemde vier deelwêrelde kan die oorkoepelende een wees en die ander is dan daarby op 'n ondergeskikte wyse ineengeskakel. In samelewings wat deur totalitaristiese regimes beheer word, oefen politici mag en politieke kontrole uit oor bloed-enbodem sake, sowel as oor die godsdiens en die ekonomie. Politiek het te doen met die verkryging van mag en die handhawing daarvan. Hoewel dit in ' $n$ groot mate so is dat politiek vandag in die hele Westerse wêreld feitlik alles beheer, moet ons ons steeds daaraan herinner dat dit nie altyd en oral so gewees het nie. Minstens godsdienstige mense moet onthou dat alles tog nie polities of ekonomies van aard is nie. Die moontlikheid moet wel oopgehou word dat die ekonomie in sterk kapitalisties georiënteerde lande die onderliggende ideologiese krag kan wees. Daar is egter ook samelewings waar families en die hoofde van families die kontrole uitoefen. In sulke samelewings is die ekonomie, politiek en godsdiens ingebed in 'n sosiale verwantskap wat primêr deur geboorte en nasionaliteit bepaal word.

Wanneer ' $n$ mens soos hierbo na die samelewing bestaande uit verskillende sosiale verbande as deelwêrelde kyk en 'n mens stem saam dat hulle as ideologiese kragte kan funksioneer, dan sal daar begrip vir die standpunt wees dat die uitdrukking 'sosiaal-veragtes' telkens in terme van die onderskeie situasies op iets anders betrekking kan hê (kyk Malina 1986; 1987). In sekere samelewings kan hulle die behoeftiges wees, omdat hulle die ekonomies ondergeskiktes is. Dit is ook moontlik dat die sosiaal-veragtes in 'n ander situasie weer op die verdruktes kan dui, omdat hulle polities verontreg word. In terme van die familie- en nasionaliteitsverwantskap kan die kinderloses, die melaatses en die vreemdelinge die sosiaal- veragtes wees. Maar dit kan ook die 'ongelowige' in die religieuse sin van die woord wees. Die vraag is, wat het dit ingehou om as die 'sosiaal-veragte' tydens die aardse Jesus se lewe geklassifiseer te word?

\subsection{Die 'volk van die land'}

In die gebied oos van die Middelandse See tydens die Hellenistiese periode was die ekonomie op sigself nie die oorkoepelende ideologiese krag nie. Dit het wel later sedert die negentiende-twintigste-eeuse tegnokrasie in 'n sekere mate die geval geword in sommige dele van die Eerste Wêreld en lande wat hierop gemodelleer is. Die moontlikheid is derhalwe groot dat ons vandag Nuwe-Testamentiese gegewens in verband met die sosiaal-veragtes op 'n misplaaste wyse kan konkreti- 
seer. Armoede en rykdom in die Nuwe-Testamentiese tyd was ingebed in ' $n$ sosio-religieuse struktuur wat deur bloed-en-bodem, familie- en familiehoofde en magspolitiek beheers was. Natuurlik het die kontrole wat familieverbande en politiek uitgeoefen het, sosio-ekonomiese gevolge gehad. Ons sal egter die verkeerde spoor volg deur die sosiaal-veragtes primêr te bedink in terme van sosio-ekonomiese aangeleenthede. Dit is daarom nie 'n verrassing nie dat al hoe meer ondersoekers van die ontstaan van die kerk daarvan oortuig raak dat die Christendom na die dood en opstanding van Jesus nie as ' $n$ proletariaatsbeweging begin het nie.

Wat die politiek betref, is dit betekenisvol dat die Christendom sy verskyning in die wêreldgeskiedenis gemaak het toe die 'universele' Romeinse Ryk sy hoogtepunt bereik het (kyk Baur 1860). Bepaalde faktore voortspruitend uit die universele politiek van daardie tyd het die Christendom bevoordeel. Daar kan in hierdie verband byvoorbeeld gewys word op die bydrae wat die baie nuwe en goeie verkeersweë en wat rykdom as sodanig tot die uitbreiding van die Christendom in die Romeinse provinsies gelewer het.

Wat magspolitiek betref, kan diegene wat die mag gehad het, die 'aristokrate' genoem word en die wat sonder politieke mag was, die 'volk van die land'. Laasgnoemde was wat die beroepslewe betref, mense wat beroepe soos ' $n$ ambag, landbouer, visser ensovoorts beoefen het. Jesus self kom uit 'n huishouding waar die huiseienaar 'n ambagsman was (kyk Mark 6: 3). Sy aardse pa was 'n timmerman. Petrus en ander van Jesus se dissipels was vissers van beroep (kyk Mark 1: 16). Paulus was ook 'n ambagsman, te wete 'n tentmaker (kyk Hand 18: 3 en 1 Kor 9: 6). Die 'aristokrate' het min of meer vyf persent van die bevolking uitgemaak en die 'volk van die land' ongeveer vyf en negentig persent. Dié twee sosiale verbande het vir alle praktiese doeleindes as twee aparte samelewings bestaan (Stark 1986).

Oor die vraag wie en wat die 'volk van die land' was, bestaan daar onder kenners verskillende menings (kyk Seccombe 1982). Die term kom weliswaar nie in die Nuwe Testament self voor nie. Dit is ' $n$ uitdrukking wat eers in die Rabbynse literatuur na $-70 \mathrm{n} C$ voorkom. Die sosio-religieuse groepering waarop die term 'volk van die land' betrekking gehad het, het egter nie in die periode vóór die val van Jerusalem in $70 \mathrm{n} \mathrm{C}$ wesenlik anders daar uitgesien nie. Daar is geleerdes wat reken dat ons die 'volk van die land' as die nie-Farisese deel van die bevolking in die tyd van Jesus moet beskou. So ' $n$ klassifisering neem egter nie die sosiale verbande van daardie tyd 
genuanseerd genoeg in ag nie. Ander geleerdes reken weer die 'volk van die land' was oningeligte mense met betrekking tot die baie wetsvoorskrifte. Daar is ook die mening dat hulle besonderlik die voorskrifte rakende gebed en tiendes verontagsaam het. Al hierdie menings hou egter nie rekening met die basiese onderskeid tussen die sogenoemde 'aristokrate' en die res, naamlik die 'volk van die land' nie (kyk Blasi 1986).

Die 'volk van die land' was hoegenaamd nie polities bewus of aktief en daar was ook geen klassekonflik tussen hulle en die maghebbers soos in die sin van die Marxistiese teorie rakende die have's en die have not's nie. Sporadiese opstande het wel onder die 'volk van die land' uitgebreek. Sulke periodieke oproerigheid was gewoonlik geïnstigeer deur die uitbuiting van die 'volk van die land' deur die 'aristokrate'. Dié uitbuiting het hoofsaaklik betrekking gehad op belasting- en militêre maatreëls. Die 'volk van die land' het oor die algemeen binne hulle eie klein wêreld voortbestaan. Dit was 'n samelewing wat gekenmerk is deur sy passiewe gehoorsaamheid en onderwerping aan plaaslike owerhede. Hulle het nie ' $n$ interesse gehad in politieke magsverkryging nie. Hulle was waarskynlik nie eers sterk bewus van streeks- en nasionale magstryd nie.

Die a-politiese houding van die Fariseërs in die periode voor $-70 \mathrm{n} \mathrm{C}$ was binne die samelewing van die 'volk van die land' deel van die algemene lewenspatroon. Daar was wel 'n Joodse groep wat as die 'Selote' bekend gestaan het en wat ten doel gehad het om die Romeinse gesag omver te werp. Hulle het egter nie deel gevorm van die stabiele en geordende huishoudings van die 'volk van die land' nie. Dit wil wel lyk of die 'Selote' deels daarvoor verantwoordelik was dat sekere mense rondom Jesus politieke aspirasies van Hom verlang het. Daar was selfs 'n 'Seloot' onder die Twaalftal dissippels (kyk Luk 6: 15). Jesus het egter sulke tipe verwagtinge ferm afgewys (kyk Joh 18: 36). In hierdie verband moet ons ook onthou dat die messiaanse Seun-van-Dawid verwagting nie in alle gevalle polities geïnspireer was nie. Dit kan onder andere daarin gesien word dat die aanspreekvorm 'Seun-vanDawid' vir Jesus deur die Joodse skare in die Matteusevangelie altyd in verband met genesings, veral genesing van blindes (kyk Matt 12: 9-13, 22-23), funksioneer (kyk Van Aarde 1987b). Aan die ander kant is dit nie vreemd dat die benaming 'Koning-van-die-Jode' met betrekking tot Jesus in die Matteusevangelie vanuit die gesigshoek van die 'aristokrate' politieke konnotasies gehad het nie. Dit geld vir Herodes die Grote (Matt 2: 2, 4, 13, 16), Pilatus en die Romeinse offisier (Matt 27: 11, 17, 22 , 
29, 37), die Romeinse soldate (Matt 27: 27-31) en lede van die Joodse Sanhedrin (Matt 26: 63, 68; 27: 37, 41-42).

Ons het hierbo die 'volk van die land' gedefinieer as dié sosiale groepering wat in die Palestynse situasie van die eerste eeu diegene was wat nie die politieke mag gehad het nie. Dit het hulle egter oor die algemeen nie gepla nie. Die 'volk van die land' was as sosiale groep ingebed in familie- en nasionaliteitsverwantskap. As ' $n$ beweging van Jode het die Christendom baie spoedig 'n beweging van Helleniste en ander geword. Hierdie assimilasie, hoewel dit een van die ernstige krisisse in die vroeë kerk as gevolg van intense konflikte meegebring het, is waarskynlik gebore uit die feit dat die Jesus-saak in Galilea begin het. Jesus self was 'n Galilese Jood en ons kan aanvaar dat Hy aan Hellenistiese invloed blootgestel was (kyk o a Mark 7: 24, 26). Naas Hebreeus en Aramees, moes Hy ook Grieks kon gepraat het (vgl o a sy antwoorde op Pilatus as vrae). Galilea self word beskryf as die 'plek van die nasies' (kyk Matt 4: 15).

Die 'volk van die land' was binne so 'n konteks egter steeds nasionaal-partikulier georiënteer en het nie maklik met nie-Jode gemeng nie (kyk Joh 4: 9). Kontak is ook vermy met die mense op die straat, dit wil sê met mense soos bedelaars en melaatses (kyk Luk 17: 14, 16b). Dit het ook vir die tollenaars as belastinginsamelaars gegeld (kyk Luk 19: 7). Allerlei reinheidsvoorskrifte moes in hierdie verband nagekom word. Wanneer Jesus volgens Lukas 19: 10 sê dat Hy gekom het om te red wat verlore is en volgens Lukas 4:18 om die evangelie aan armes te verkondig, dan het Hy nie alleen die ekonomiese armes in die oog gehad nie. Hy het gekom om vrede te bring vir diegene wat die veragtes in die sosiale konteks van hoofsaaklik die 'volk van die land' was: Diewe, bedrieërs, egbrekers, tollenaars, siekes, blindes, ongelowiges ensovoorts (kyk oa Luk 18: 11; 4: 18-19). As 'n lid van die 'volk van die land' het Jesus vir sy mense, maar ook vir aristokrate en nie-Jode, getoon en geleer hoe om ook in neerdrukkende omstandighede, ten spyte van allerlei vooskriftelike beperkinge, op God se teenwoordigheid staat te maak. Waar vergifnis van sonde by die 'sondaar' nodig is voordat 'vrede met God' herstel kan word, skenk God dit sonder menslike teenprestasie (kyk Luk 17: 18; 18: 13-14).

\subsection{God-by-ons}

Indien ons vanuit twintigste-eeuse ekonomiese en politieke verbande dink en ons kategoriseer die sosiaal-veragtes onder die ekonomiese 
armes en politieke ongelukkiges, dan dink ons basies in terme van 'meerderes' en 'minderes' vanuit die perspektief van 'n sosiale konteks waar politieke en ekonomiese verbande die botoon voer. Ons sou ook in die lig van ons twintigste-eeuse situasie vir Jesus as Seun van God by die 'meerderes' in ' $n$ religieuse sin van die woord laat tuishoort. Die 'diakensrol' van Jesus (kyk Luk 22: 27) sou ons dan vertolk as dié van 'n 'meerdere' wat ' $n$ 'mindere' bedien en die posisies omkeer. Ons het egter op grond van ons bespeking hierbo wys geword dat alleen 'n klein minderheid in die Hellenistiese periode politieke kontrole uitgeoefen het. Die res, die 'volk van die land', was eintlik a-polities georiënteerd. As Jood was Jesus ' $n$ lid van die 'volk van die land'. Indien ons steeds vanuit die gesigshoek van moderne kategorieë dink, sal ons dus die verhouding van Jesus en die sosiaal-veragtes nie as dié van teenoorstaandes beskou nie. Ons het egter ook gesien dat die rede waarom iemand as ' $n$ sosiaal-veragte gereken word, verband hou met die aard van die spesifieke samelewing. So iemand sal waarskynlik by ons vandag 'n ekonomiese en politieke verontregte wees. Dit was egter nie die geval in die tyd van Jesus nie.

'n 'Arme' in die tyd van Jesus was waarskynlik iemand wat sy/haar posisie nie kon handhaaf as ongelukkige omstandighede hom/haar en sy/haar familie oorval nie. Hierdie omstandighede kon skuld behels, ballingskap in 'n vreemde land, siekte, dood van 'n eggenoot of een of ander persoonlike fisiese gebrek. Hierdie soort ongeluk is gesien as geïnstigeer deur Satan en sy agente. Wat die 'armes' betref, is dit duidelik dat hulle nie beskou moet word as 'n sosiaal gestruktureerde klas nie. Daarom is dagloners, plattelanders sonder grondbesit, bedelaars ensovoorts nie op sigself die 'armes' nie. Die 'armes' is nie as sodanig 'n ekonomiese kategorie nie. Die alternatief van die 'arme' is derhalwe ook nie noodwendig die 'ryke' nie. 'n 'Arme' kon iemand onder die ekonomies ryk aristokrate gewees het, soos Saggeus in Lukas 19: 1-10 omdat hy 'n 'sondaar', ofte wel 'n 'verlorene', genoem. is.

Wanneer ons ten besluite die sosiaal-veragte wel as die 'arme' definieer, doen ons dit in die sin van iemand wat binne die sosiale konteks van die tyd van Jesus nie in staat was om sonder barmhartigheidsondersteuning voort te bestaan nie. Dit kon die 'arme' weduwee wees (Luk 21: 1-4) wat net twee kopergeldstukke gehad het en ook die 'arme' bedelaar by die ryk man se hek (Luk 16: 19-21) wat net soos die stom, verlamde en blinde, nie in staat was om enige terugbetaling te maak aan diegene wat vir hulle gehelp het nie. Maar dit kon ook Levi, die tollenaar as lid van die aristokrasie, wees wat 'siek' was en 'n dokter 
nodig gehad het (Luk 6: 27-32), of die Herodiaan, die Galilese regeringsamptenaar, wie se seun sterwend was (Joh 4: 43-54) of die 'ongelowige' Griekssprekende Siro-Fenisiese vrou met die 'duiwelbesete' kind (Mark 7: 24-30) wat die oorskiet brood nodig het wat van die eettafel afval en wat die hondjies normaalweg kry. Sulke mense is die mense, soos diegene in die Psalms, wat in nood is en hulle kommer voor God bely want God is hulle enigste beskermer. Hulle is soos die sterwende Jesus wat soos ander Joodse martelare met die woorde van Psalm 22: 2 God se teenwoordigheid bely wanneer dit na Godverlatenheid lyk (Matt 27: 46).

\section{DIE BEVRYDENDE IMPLIKASIES VAN DIE JESUS-EVANGELIE}

Vandag word die Jesus-evangelie toenemend gebruik as 'n manifes om die armes en die verdruktes te bevry (kyk Samuel \& Sugden 1982). Gevolge van só 'n bevrydingsboodskap is dat die Jesus-saak, volgens Schillebeeckx (1987), uitgedruk word in ekonomiese en politieke terme soos die 'privilege of the oppressed poor' en 'political holiness'. 'Kyk ek na 'n vryheidsvegter, sien ek vir Jesus', het 'n Afrika-staatshoof en geestelike by 'n onlangse geleentheid gesê (kyk ook Banana 1981). Maar ook die 'onderdrukker' kan soos die 'bevryder' die Jesus-evangelie as 'n God-is-aan-ons-kant teologiese dokument misbruik. Wat is die implikasies van ons verstaan van die eerste-eeuse Jesus en die sosiaalveragtes vir só 'n twintigste-eeuse ekonomiese en politieke God-is-aanons-kant teologie?

In die lig van ons konstruksie van die sosiale konteks van die aardse Jesus, het dit geblyk dat die 'sosiaal-veragtes' in werklikheid by die aristokrate as die politieke maghebbers sowel as by die 'volk van die land' voorgekom het. Navorsing het getoon dat in die Sinoptiese Evangelies agtien tipe ongelukkige mense as die sosiaal-veragtes in terme van 'armes' beskou kan word met wie Jesus bemoeienis gehad het (kyk Hollenbach 1987). Hulle 'ongeluk' was die gevolg van òf 'natuurlike' oorsake ò sosiale omstandighede. Die meeste was siek mense of gestremdes, te wete blindes (Luk 4: 18; Matt 11: 5; Luk 14: 13, 21), verlamdes (Matt 11: 5; Luk 14: 13, 21), melaatses (Matt 11: 5; Luk 16: 19-31), dowes (Matt 11: 5), en siekes in die algemeen (Matt 25: 31-46). Hierdie groep vorm ses van die gemelde agtien tipe sosiaal-veragtes. Dertien vorm ' $n$ kategorie wat verband hou met ontworteling met betrekking tot familie-aangeleenthede, te wete die treurendes (Matt 5: 3 
vv), hongeriges (Matt 5: 3 vv; 25: 31-46; Luk 16: 19-31), dorstiges (Matt 5: $3 \mathrm{vv}$; 25: 31-46); melaatses (Matt 11: 5; Luk 16: 19-31), dowes (Matt 11: 5), dooies (Matt 11: 5), verlamdes (Luk 14: 13, 21), weduwees (Mark 12: 42-43), huisloses (Luk 16: 19-31), bedelaars (Luk 16: 19-31; Matt 25: 31-46), vreemdelinge (Matt 25: 31-46), naaktes (Matt 25: 31-46) en siekes in die algemeen (Matt 25: 31-46). Vyf vorm 'n kategorie wat met ekonomiese probleme te doen het, te wete die hongeriges, dorstiges, huisloses, bedelaars en dié sonder klere. Slegs vier groepe van die 'sosiaal-veragtes' kan volgens Hollenbach (1987) op een of ander manier met politieke mag (mis)bruik in verband gebring word, te wete die gevangenes (Luk 4: 18; Matt 25: 31-46), onderdruktes (Luk 4: 18), sagmoediges (Matt 5: $3 \mathrm{vv}$ ) en die melaatses.

Op grond van bogenoemde inligting behoort dit duidelik te wees dat die uitdrukking van die Jesus-evangelie in ekonomiese en politieke terme, soos die 'privilege of the oppressed poor' en 'political holiness', neerkom op misplaaste konkretisering van die aardse Jesus se houding teenoor die sosiaal-veragtes van sy tyd. Die boek van Schottroff en Stegemann (1978) is hieraan skuldig. ' $n$ God-is-aan-ons-kant teologie is misleidend en vir die geloof ondermynend (vgl ook Schillebeeckx 1987 se kritiese opmerkings). Selfbevredigende barmhartigheid word ook nie in die Jesus-saak teruggevind nie. Waarop die bevrydende implikasies van die Jesus-saak met betrekking tot God se beskerming en omgee vir diegene wat op Hom vertrou, neerkom, is dat Jesus aan die kant is van wat 'goed' is. En wat vir die mens in nood 'goed' is, is om in die woorde van Psalm 146: 3 nie op magtiges te vertrou nie, nie op 'n mens nie want hy kan jou nie red nie.

'Armes' wat daarom weet hoe afhanklik hulle van God is (Matt 5: 3), begin ervaar dat die 'aristokraat' Saggeus uit sy oorvloed teruggee aan hulle wat hy ekonomies en polities gemanipuleer het (Luk 19: 8). So kan ons almal begin ervaar en begin om voort te bestaan met die troosvolle wete dat Jesus in ons kring is soos die een wat dien (Luk 22: 27b). En ons begin vir God dank dat die 'bevoorregte' mense van die vroegste kerk die 'evangelie vir die armes' wêreldwyd gaan verkondig het.

\section{Literatuurverwysings}

BANANA, C 1981. The Gospel according to the ghetto. Gwelo: Mambo.

BAUR, FC 1860. Das Christentum und die christliche Kirche der drei ersten Jahrhunderte. Zweite, neu durchgearbeitete Ausgabe. Tübingen: Mohr.

BLASI, AJ 1986. Rolestructuresin theearlyHellenisticchurch. Sociological Analysis43, 226-248. 
BUCHANAN, GW 1964/5. Jesus and the upper class. Novum Testamentum 7, 195-209.

GRANT, FC 1956. The economic background of the New Testament, in Davies, WD \& Daube, D (eds), The background of the New Testament and its eschatology: In honour of Charles Harold Dodd, 96-114. Cambridge: Cambridge University Press.

HAHN, F, 1986. Die Petrusverheissung Mt 16, 18f: Eine exegetische Skizze, in Exegetische Beiträge zum ökumenischen Gespräch: Gesammelte Aufsätze, Band I, 185-200. Göttingen: Vandenhoeck.

HOLLENBACH, P 1987. Defining rich and poor: Using social sciences, in Richards, $\mathrm{KH}$ (ed), Society of Biblical Literature 1987 Seminar Papers, 50-63. Atlanta: Scholars.

JEREMIAS, J 1978. New Testament theology, Volume One: The proclamation of Jesus. Fifth impression. Transl by J Bowden. London: SCM.

KECK, LE 1965. The poor among the saints in the New Testament. ZNW 56, 100-129.

LUZ, U 1982. Jesus und die Pharisäer. Judaica 38, 229-246.

MALINA, BJ 1981. The New Testament world: Insights from cultural anthropology. Atlanta: John Knox.

MALINA, BJ 1986. Interpreting the Bible with anthropology: The case of the poor and the rich. Listening 21, 148-159.

MALINA, BJ 1987. Wealth and poverty in the New Testament and its world. Interpretation 41, 354-367.

MEEKS, WA 1983. The first urban Christians: The social world of the Apostle Paul. New Haven: Yale University Press.

SAMUEL, V \& SUGDEN, C (eds) 1982. Evangelism and the poor: A Third World study guide. Revised edition. Oxford: Regnum Books.

SCHILLEBEECKX, E 1987. Jesus in our Western culture: Mysticism, ethics and politics. Transl by J Bowden. London: SCM.

SCHMIDT, KL 1968, s v ekklessia. TDNT, Vol III. Third printing. Grand Rapids: Eerdmans.

SCHNELL, CV \& DE KLERK, JC 1987. A new look at Jesus: Literary and sociological interpretations of Mark and John. Pretoria: Van Schaik.

SCHOTTROFF, L \& STEGEMANN, W 1978. Jesus von Nazareth: Hoffnung der Armen. Stuttgart: Kohlhammer.

SECCOMBE, DP 1982. Posessions and the poor in Luke-Acts. Linz: A Fuchs. (SNTU, Serie B, Band 6.)

STARK, R 1986. The class basis of early Christianity: Inferences from a sociological model. Sociological Analysis 47, 216-225.

VAN AARDE, AG 1987a. Gedagtes oor die begin van die kerk: 'n Geskiedenis van versoenende verskeidenheid. HTS 43, 325-351.

VAN AARDE, AG 1987b. Immanuel as die geinkarneerde tora: Funksionele Jesusbenaminge in die Matteusevangelie as vertelling. HTS 43, 242-277.

VERMES, G 1983. Jesus and the world of Judaism. London: SCM.

WILD, RA 1985. The encounter between Pharisaic and Christian Judaism: Some early Gospel evidence. Novum Testamentum 27, 105-124. 